\title{
PENGARUH PENGETAHUAN AWAL, KEDISIPLINAN BELAJAR, DAN IKLIM KOMUNIKASI KELAS TERHADAP HASIL BELAJAR PRODUKTIF AKUNTANSI SISWA KELAS XI JURUSAN AKUNTANSI SMK NEGERI 3 BANGKALAN
}

\author{
Veronika Tri Handayani, SMKN 3 Bangkalan \\ veronika.indah@yahoo.co.id
}

\begin{abstract}
ABSTRAK
Penelitian ini bertujuan untuk menganalisis pengaruh pengetahuan awal, kedisiplinan belajar, dan iklim komunikasi kelas terhadap hasil belajar produktif Akuntansi siswa kelas XI jurusan Akuntansi SMK Negeri 3 Bangkalan baik secara simultan maupun parsial. Teknik sampling yang digunakan dalam penelitian ini adalah Simple Random Sampling, dengan jumlah sampel sebanyak 113 responden. Teknik analisis data adalah analisis regresi linear berganda. Hasil penelitian menunjukkan bahwa: ada pengaruh signifikan pengetahuan awal, kedisiplinan belajar, dan iklim komunikasi kelas secara simultan terhadap hasil belajar; ada pengaruh signifikan pengetahuan awal secara parsial terhadap hasil belajar; ada pengaruh signifikan kedisiplinan belajar secara parsial terhadap hasil belajar sebesar; ada pengaruh signifikan iklim komunikasi kelas secara parsial terhadap hasil belajar.
\end{abstract}

Kata-kata kunci : Pengetahuan Awal, Kedisiplinan Belajar, Iklim Komunikasi Kelas, Hasil Belajar Siswa

\begin{abstract}
This study aims to analyze the effect of prior knowledge, learning discipline and classroom communication climate on productive accounting learning student class XI accounting in SMK Negeri 3 Bangkalan. The population in this study is class XI student of Accounting at SMK Negeri 3 Bangkalan as many as 157 students. In this study, sampling was simple random sampling, with a total sample of 113 respondents.Techniques or methods of data collected by questionnaires and documentation. The method used is quantitative. Data analysis techniques are multiple linear regression analysis. The results showed that: There was a simultaneously significant effect of prior knowledge, learning discipline and classroom climate communication to the learning outcomes; There is a significant effect of initial partial knowledge of the learning outcomes; There was a partial significant effect of discipline to the learning outcomes; There was a partial significant effect of class communications climate to the learning outcomes.

Keywords: Prior Knowledge, Dicipline Learning, Communication Climate Class, and Student Results.
\end{abstract}

\section{PENDAHULUAN}

Sumber daya manusia yang unggul dan berkualitas tentu tidak bisa lepas dari masalah pendidikan. Pendidikan merupakan suatu proses dalam membentuk, mengarahkan, dan mengembangkan kepribadian serta kemampuan seseorang. 
Pendidikan diharapkan mampu meningkatkan kualitas sumber daya manusia untuk memajukan ilmu pengetahuan dan teknologi. Pendidikan dapat dilaksanakan melalui beberapa jalur dan salah satu di antaranya adalah pendidikan formal yang diselenggarakan di sekolah. Sekolah sering dijadikan tumpuan utama masyarakat dalam menilai berhasil tidaknya pendidikan. Salah satu indikator keberhasilan suatu pendidikan dapat dilihat dari hasil belajar siswa.

Pendidikan Menengah Kejuruan atau SMK sebagai bagian dari sistem pendidikan di Indonesia, sesuai dengan Undang Undang Republik Indonesia No. 20 tahun 2003 tentang Sistem Pendidikan Nasional pada pasal 15 yang menegaskan bahwa: "Pendidikan kejuruan merupakan pendidikan menengah yang mempersiapkan peserta didik terutama untuk bekerja dalam bidang tertentu." Oleh karena itu, Sekolah Menengah Kejuruan (SMK) dirancang untuk menyiapkan peserta didik yang memiliki kemampuan, keterampilan, dan keahlian, sehingga lulusannya siap memasuki dunia kerja dan mampu mengembangkan sikap profesional pada bidang pekerjaannya.

SMK Negeri 3 Bangkalan merupakan salah satu Sekolah Menengah Kejuruan yang dapat menciptakan lulusan dengan memiliki kemampuan, keterampilan serta ahli dalam bidang tertentu, salah satunya yaitu pada jurusan Akuntansi. Tujuan jurusan Akuntansi di SMK adalah membekali tamatan dengan berbagai kompetensi Akuntansi agar mereka menguasai dan mampu menerapkan konsep-konsep dasar, prinsip maupun prosedur Akuntansi yang benar, untuk kepentingan melanjutkan pendidikan ke perguruan tinggi maupun memasuki dunia kerja.

Berdasarkan hasil pengamatan terhadap siswa kelas XI SMK Negeri 3 Bangkalan terdapat empat kelas untuk jurusan Akuntansi antara lain kelas AK.1 sebanyak 40 siswa, kelas AK.2 sebanyak 38 siswa, kelas AK.3 sebanyak 39 siswa, dan Kelas AK.4 sebanyak 40 siswa. Hasil belajar SMK Negeri 3 Bangkalan menunjukkan bahwa $40 \%$ dari total siswa nilai ulangan hariannya masih kurang dari kriteria ketuntasan minimal (KKM) sehingga harus mengikuti remidial, dan $60 \%$ dari total siswa nilai ulangan hariannya memenuhi standar kriteria ketuntasan minimal (KKM). Dimana nilai KKM yang sudah ditetapkan sebesar 77.

Apabila melihat pencapaian hasil belajar siswa dan membandingkannya dengan standar yang telah ditetapkan, dapat diketahui bahwa tingkat pencapaian hasil belajar siswa masih belum maksimal. Padahal Akuntansi merupakan salah satu mata pelajaran yang penting bagi siswa program keahlian Akuntansi. Hasil belajar siswa yang belum maksimal ini, dilatarbelakangi oleh beberapa fenomena.

Fenomena pertama yang terlihat di kelas XI jurusan Akuntansi, masih banyak ditemukan adanya kesenjangan nilai ulangan harian siswa. Terdapat siswa yang memiliki nilai ulangan harian yang sempurna namun terdapat pula siswa yang memiliki nilai ulangan harian yang rendah dibawah kriteria ketuntasan minimal (KKM). Bila dirujuk kembali, semua siswa kelas XI jurusan Akuntansi telah menerima pelajaran produktif Akuntansi perusahaan jasa saat menempuh kelas X jurusan Akuntansi sebagai dasar pengetahuan awal untuk mempelajari Akuntansi perusahaan dagang di kelas XI jurusan Akuntansi.

Fenomena kedua menunjukkan bahwa mata pelajaran produktif Akuntansi merupakan mata pelajaran yang membutuhkan pemahaman lebih. Namun, kebanyakan siswa masih memiliki keyakinan diri yang rendah untuk bisa 
memahami ilmu yang dipelajari. Sehingga, diperlukan kedisiplinan belajar yang harus ditingkatkan, baik itu kedisiplinan dalam belajar di lingkungan sekolah maupun di rumah.

Fenomena berikutnya terlihat pada siswa kelas XI jurusan Akuntansi kurang mengembangkan iklim komunikasi di kelas selama pembelajaran berlangsung. Iklim komunikasi yang dimaksud adalah adanya umpan balik interaktif antara guru dan peserta didik, dengan demikian siswa akan mampu memberikan respon balik terhadap materi pembelajaran secara aktif, tidak perlu menunggu informasi dari guru pengajar. Pada siswa kelas XI jurusan Akuntansi ini kurangnya keaktifan dalam proses belajar mengajar di kelas sehingga perlu adanya hubungan sosial yang baik dalam melestarikan iklim komunikasi di kelas antara guru dengan siswa.

Dari fenomena diatas dapat diketahui rendahnya hasil belajar siswa untuk mata pelajaran produktif Akuntansi antara lain disebabkan oleh kurangnya pengetahuan awal, masih rendahnya kedisiplinan belajar, dan kurangnya komunikasi antara guru dengan murid sehingga suasana di kelas menjadi tidak nyaman, sehingga berdampak pada proses belajar mengajar.

Dalam konteks pembelajaran, pengetahuan awal (prior knowledge) dapat diartikan sebagai kemampuan awal yang dimiliki siswa dan dapat dijadikan sebagai titik tolak ukur untuk melihat seberapa besar perubahan perilaku yang terjadi setelah siswa mengikuti proses pembelajaran. Menurut Kujawa \& Huske (2003) menyatakan bahwa pengetahuan awal tidak hanya berkaitan dengan aspek pengetahuan saja, tetapi juga menyangkut sikap dan pengalaman yang telah dimiliki siswa selama belajar. Sikap meliputi keyakinan diri, kesadaran akan minat dan kekuatan yang dimiliki, motivasi dan hasrat belajar. Pengalaman meliputi berbagai aktivitas yang dilakukan sehari-hari, berbagai peristiwa dalam kehidupan, dan berbagai pengalaman yang terjadi di keluarga maupun komunitas dan pengetahuan meliputi tentang proses dan konten belajar, termasuk didalamnya adalah pengetahuan tentang tujuan belajar dan tujuan pribadinya.

Indikator dari pengetahuan awal dapat diklasifikasikan sebagai berikut: (1) Sikap adalah keadaan diri yang menggerakkan untuk bertindak atau berbuat dalam kegiatan pembelajaran Akuntansi sehingga dapat memperoleh banyak keuntungan dan bermanfaat dengan mendapatkan nilai yang memuaskan; (2) Pengalaman adalah suatu proses pembelajaran dan perkembangan tingkah laku baik dari pendidikan formal maupun non formal serta dapat menerapkannya di dalam masyarakat dan lingkungan sekitar; (3) Pengetahuan adalah ingatan tentang sesuatu yang diketahuinya baik melalui pengalaman, belajar, atau informasi yang diterima dari guru pengajar, sehingga bisa lebih mengerti dan memahami ilmunya serta dapat diterapkan dilingkungan kerja maupun masyarakat.

Sedangkan menurut Santyasa (2005) menyatakan bahwa secara umum pengetahuan awal berpengaruh langsung dan tidak langsung terhadap proses pembelajaran. Secara langsung, pengetahuan awal dapat mempermudah proses pembelajaran. Secara tidak langsung, pengetahuan awal dapat mengoptimalkan kejelasan materi-materi pembelajaran dan meningkatkan efisiensi penggunaan waktu belajar dan pembelajaran. Selain itu, pengetahuan awal mempengaruhi perasaan siswa dalam menilai informasi yang di presentasikan dalam sumbersumber belajar dalam kelas. Model pembelajaran tidak dapat mencapai hasil yang optimal apabila kurang memperhatikan pengetahuan awal siswa. 
Menurut Suwardjono (2001) tingkat pemahaman Akuntansi dapat diwujudkan pada nilai yang diperoleh siswa. Nilai yang diperoleh siswa mempunyai fungsi ganda, sebagai ukuran keberhasilan siswa dalam mempelajari mata pelajaran Akuntansi dan sekaligus sebagai alat evaluasi keberhasilan mata pelajaran itu sendiri. Dalam hal tertentu, nilai yang diperoleh siswa merupakan indikator kesuksesan siswa dalam menempuh proses belajar mengajar, tetapi mungkin bukan merupakan ukuran keberhasilan pencapaian tujuan atau sasaran pengajaran mata pelajaran dalam mengubah pengetahuan, perilaku atau kepribadian siswa termasuk penalarannya.

Kedisiplinan belajar siswa adalah sikap yang sangat diperlukan dalam proses belajar karena dengan disiplin yang tinggi siswa dapat belajar dengan teratur dan dapat meraih prestasi yang baik. Disiplin belajar merupakan kondisi yang sangat penting dan ikut menentukan keberhasilan siswa dalam proses pembelajaran. Indikator dari kedisiplinan belajar dapat diklasifikasikan sebagai berikut: (1) Sikap mental adalah potensi atau pendorong yang ada dalam diri siswa untuk bereaksi terhadap segala hal yang ada dalam lingkungannya dan dapat berpengaruh positif; (2) Pemahaman adalah kemampuan untuk mengerti atau memahami sesuatu setelah sesuatu itu dapat diketahui dan diingat. Siswa dikatakan memahami apabila dapat memberikan penjelasan atau memberikan uraian yang lebih rinci tentang hal-hal yang dipelajari; (3) Sikap perilaku adalah sikap untuk menyesuaikan diri dan bertindak dalam kegiatan pembelajaran serta dapat menanggapi situasi atau kondisi lingkungan didalam kelas dan sekolah serta di rumah berupa kesungguhan hati selama belajar, sikap perilaku siswa dapat dinilai dengan hasil prestasi belajar yang tinggi.

Menurut Soegeng (2003) menyimpulkan bahwa disiplin merupakan suatu kondisi yang tercipta dan terbentuk melalui proses dari serangkaian perilaku yang menunjukkan nilai-nilai ketaatan, kepatuhan, kesetiaan dan keteraturan atau ketertiban. Nilai-nilai tersebut telah menjadi bagian perilaku dalam kehidupannya dan perilaku tersebut tercipta melalui proses binaan melalui keluarga, pendidikan, dan pengalaman.

Adanya disiplin diri dalam belajar siswa, dapat memudahkan keberhasilan dan kelancaran belajar siswa, agar siswa selalu dapat menerapkan disiplin, sekolah perlu menerapkan kedisiplinan belajar. Hal ini diadakan pembinaan dan penanaman rasa tanggung jawab kepada siswa. Cara-cara yang ditempuh dalam pelaksanaan disiplin belajar, siswa dapat melakukannya di sekolah maupun di rumah. Untuk menanamkan disiplin belajar siswa memerlukan adanya kerjasama dari pihak sekolah dengan pihak orang tua siswa. Dengan demikian, siswa akan terbiasa selalu berdisiplin kapan pun dan dimana pun.

Iklim komunikasi kelas adalah kualitas lingkungan kelas dalam berkomunikasi yang mempengaruhi tingkah laku siswa dalam menciptakan proses pembelajaran yang kondusif. Indikator iklim komunikasi kelas dapat diklasifikasikan sebagai berikut: (1) Suasana kelas dan sekolah adalah salah satu faktor dari suasana belajar yang dijadikan sebagai faktor penentu keberhasilan mencapai sasaran belajar. Seorang guru idealnya kreatif mendesain lingkungan belajar, adanya kekompakan dan kedekatan dengan siswa, serta sarana pendukung pembelajaran yang lengkap sehingga tercipta suasana kelas dan sekolah yang menyenangkan; (2) Komunikasi antara siswa dan guru adalah kegiatan interaksi 
antara guru dan siswa,yang dapat menghubungkan komunikasi yang interaktif antara guru dengan siswa yang dapat mencapai tujuan pembelajaran.

Menurut Hoy dan Miskell (2000) menyatakan bahwa iklim komunikasi kelas merupakan kualitas lingkungan kelas dalam berkomunikasi dan terusmenerus dialami oleh guru yang mempengaruhi tingkah laku siswa dalam menciptakan proses pembelajaran yang kondusif. Sedangkan menurut Silalahi (2008) iklim komunikasi di kelas dapat terjadi apabila siswa dan guru saling terbuka, terjalinnya hubungan antar pribadi yang akrab, sikap saling menghargai satu dengan yang lain, menghormati satu sama lain, dan mendahulukan kepentingan bersama.

Hasil Belajar adalah hasil dari proses pembelajaran yang ditunjukkan dalam bentuk nilai kemampuan akademik yang diperoleh siswa. Hasil belajar siswa mencakup pengukuran atau penilaian tingkah laku secara menyeluruh yang terdiri dari bidang kognitif (penguasaan pengetahuan), afektif (sikap), dan psikomotorik (keterampilan) secara terpadu pada diri siswa. Indikator dari hasil belajar pada penelitian ini adalah nilai ulangan harian.

Menurut Sudjana (2005) hasil belajar merupakan hasil dari proses pembelajaran yang ditunjukkan dalam bentuk nilai kemampuan akademik yang diperoleh siswa. Hasil belajar siswa mencakup pengukuran atau penilaian tingkah laku secara menyeluruh yang terdiri dari bidang kognitif (penguasaan pengetahuan), afektif (sikap) dan psikomotorik (keterampilan) secara terpadu pada diri siswa dan dapat dicapai dengan kriteria tertentu. Hasil belajar dapat diketahui dengan pengukuran atau penilaian. Penilaian ini dimaksudkan untuk mengetahui sejauhmana pemahaman atau penguasaan pengetahuan siswa setelah mengikuti proses pembelajaran. Sedangkan menurut Winkel (2004) menyatakan bahwa hasil belajar adalah bukti keberhasilan yang diperoleh melalui kegiatan pembelajaran di sekolah yang dinyatakan dengan angka.

Berdasarkan pemaran diatas, tujuan penelitian ini adalah mengetahui pengaruh pengetahuan awal, kedisiplinan belajar, dan iklim komunikasi kelas terhadap hasil belajar produktif Akuntansi siswa kelas XI jurusan Akuntansi SMK Negeri 3 Bangkalan baik secara simultan maupun parsial.

\section{METODE PENELITIAN}

Jenis penelitian yang digunakan adalah penelitian tingkat eksplanasi (level of explanation). Jenis penelitian tingkat eksplanasi dalam penelitian ini digunakan untuk menggambarkan bagaimana pengetahuan awal, kedisiplinan belajar, dan iklim komunikasi kelas berpengaruh terhadap hasil belajar produktif Akuntansi siswa kelas XI jurusan Akuntansi SMK Negeri 3 Bangkalan. Yang digunakan adalah penelitian tingkat eksplanasi asosiatif bentuk kausal artinya jika siswa memiliki kemampuan dasar Akuntansi yang baik kedisiplinan belajar yang tinggi dan lancarnya komunikasi di kelas maka hasil belajar terhadap mata pelajaran produktif Akuntansi di kelas XI Akuntansi juga meningkat.

Pendekatan yang digunakan dalam penelitian ini adalah pendekatan kuantitatif. Dalam penelitian ini, pendekatan kuantitatif digunakan untuk mendeskripsikan fakta-fakta atau karakteristik suatu populasi secara sistematis, faktual dan akurat tentang pengaruh pengetahuan awal, kedisiplinan belajar dan 
iklim komunikasi kelas terhadap hasil belajar produktif Akuntansi siswa kelas XI jurusan Akuntansi SMK Negeri 3 Bangkalan.

Terdapat tiga variabel bebas dalam penelitian ini yaitu pengetahuan awal $\left(\mathrm{X}_{1}\right)$, kedisiplinan belajar $\left(\mathrm{X}_{2}\right)$, dan iklim komunikasi kelas $\left(\mathrm{X}_{3}\right)$. Selanjutnya, terdapat satu variabel terikat yaitu hasil belajar (Y).

Penelitian ini dilakukan di SMK Negeri 3 Bangkalan, Jl. Martajasah No. 70 Mlajah, Bangkalan Jawa Timur. Populasi dalam penelitian ini adalah seluruh siswa kelas XI jurusan Akuntansi tahun ajaran 2013-2014 sebanyak 157 siswa dari 4 kelas. Jumlah sampel yang digunakan adalah sebanyak 113 siswa, untuk taraf kesalahan $5 \%$.

Teknik pengambilan sampel yang akan digunakan adalah probabilitas sampling. Menurut Sugiyono (2011) probabilitas sampling adalah teknik sampling yang memberi peluang sama kepada anggota populasi untuk dipilih menjadi sampel. Cara demikian sering disebut dengan random sampling atau cara pengambilan sampel secara acak.

Dalam penelitian ini menggunakan teknik pengumpulan data sebagai berikut: (1) Angket dalam penelitian ini digunakan untuk memperoleh data tentang pengetahuan awal, kedisiplinan belajar dan iklim komunikasi kelas. Dengan skala pengukuran instrumen menggunakan Skala Likert; (2) Dalam penelitian ini dokumentasi digunakan untuk mengetahui hasil belajar siswa yang diperoleh dari nilai ulangan harian Akuntansi siswa kelas XI jurusan Akuntansi SMK Negeri 3 Bangkalan.

Teknik analisis data yang digunakan dalam penelitian ini adalah analisis regresi linear berganda yaitu untuk mengetahui besarnya pengaruh pengetahuan awal, kedisiplinan belajar dan iklim komunikasi kelas terhadap hasil belajar produktif Akuntansi. Rumus regresi yang digunakan adalah :

$$
Y=a+b_{1} X_{1}+b_{2} X_{2}+b_{3} X_{3}+e
$$

Sedangkan teknik pembuktian hipotesis menggunakan uji $F$ dan uji t. Uji $F$ digunakan untuk menguji secara simultan signifikansi variabel pengetahuan awal, kedisiplinan belajar serta iklim komunikasi kelas terhadap hasil belajar produktif Akuntansi. Uji t digunakan untuk menguji secara parsial signifikansi pengaruh pengetahuan awal terhadap hasil belajar produktif Akuntansi dan kedisiplinan belajar terhadap hasil belajar produktif Akuntansi serta iklim komunikasi kelas terhadap hasil belajar produktif Akuntansi.

\section{HASIL PENELITIAN DAN PEMBAHASAN}

Berdasarkan hasil penelitian yang dilakukan, diperoleh persamaan regresi sebagai berikut:

$$
\mathrm{Y}=27,828+0,922 \mathrm{X}_{1}+1,115 \mathrm{X}_{2}+1,962 \mathrm{X}_{3}+\mathrm{e}
$$

Dari persamaan regresi tersebut, ketiga variabel bebas memiliki koefisien regresi dengan arah positif. Hal ini berarti semakin tinggi pengetahuan awal, kedisiplinan belajar dan iklim komunikasi kelas akan meningkatkan hasil belajar siswa.

Dalam penelitian ini diperoleh hasil bahwa pengetahuan awal, kedisiplinan belajar, dan iklim komunikasi kelas secara bersama-sama (simultan) berpengaruh signifikan terhadap hasil belajar produktif Akuntansi siswa kelas XI jurusan Akuntansi SMK Negeri 3 Bangkalan. Hasil uji F berdasarkan ANOVA atau uji 
statistik F, menunjukkan bahwa F hitung sebesar 51,490 dengan tingkat signifikan sebesar 0,000 kurang dari taraf signifikansi 0,05.

Berdasarkan hasil nilai koefisien determinasi sebesar 0,575 menunjukkan bahwa besarnya pengaruh pengetahuan awal $\left(\mathrm{X}_{1}\right)$, kedisiplinan belajar $\left(\mathrm{X}_{2}\right)$, dan iklim komunikasi kelas $\left(\mathrm{X}_{3}\right)$ terhadap hasil belajar $(\mathrm{Y})$ sebesar 57,5\%. Sedangkan sisanya $42,5 \%$ dipengaruhi oleh variabel lain yang tidak dibahas pada penelitian ini.

Hal ini didukung oleh teori Sudjana (2005) hasil belajar merupakan hasil yang diperoleh siswa dari proses belajar mengajar yang nampak dalam bentuk pengukuran atau penilaian tingkah laku secara menyeluruh yang terdiri dari bidang kognitif (penguasaan pengetahuan), afektif (sikap), dan psikomotorik (keterampilan) secara terpadu pada diri siswa dan dapat dicapai dengan kriteria tertentu. Hasil belajar dapat diketahui dengan pengukuran atau penilaian. Penilaian ini dimaksudkan untuk mengetahui sejauh mana pemahaman atau penguasaan pengetahuan siswa setelah mengikuti proses pembelajaran.

Hasil penelitian ini mendukung hasil penelitian terdahulu yang memiliki relevansi dengan variabel hasil belajar, yaitu penelitian Fathurrochman (2012) hasil penelitian menunjukkan bahwa secara simultan terdapat pengaruh positif dan signifikan antara pengetahuan awal siswa dan apersepsi siswa terhadap hasil pembelajaran. Hal ini berasal dari faktor intern dan faktor exstern. Faktor intern berhubungan dengan segala sesuatu yang ada pada diri siswa yang menunjang pembelajaran seperti inteligensi, bakat, kemampuan motorik pancaindra, dan skema berpikir. Faktor exstern berhubungan dengan segala sesuatu yang berasal dari luar diri siswa yang dapat menkondisikan pembelajaran seperti pengalaman, lingkungan sosial, metode balajar-mengajar, strategi belajar-mengajar, fasilitas belajar dan dedikasi guru. Keberhasilan dalam mencapai suatu tahap hasil belajar memungkinkannya untuk belajar lebih lancar dalam mencapai tahap selanjutnya.

Penelitian Rusmiasih (2013) menunjukkan pengaruh yang positif dan signifikan antara motivasi dan kedisiplinan belajar secara simultan terhadap hasil belajar ekonomi. Hasil analisis deskriptif menunjukkan bahwa motivasi siswa termasuk pada kategori cukup (35,5\%), kedisiplinan belajar pada kategori tinggi $(64,5 \%)$ dan hasil belajar ekonomi pada kategori baik $(93,5 \%)$. Berdasarkan analisis kuantitatif menunjukkan bahwa variabel motivasi secara parsial memberikan pengaruh yang positif dan signifikan terhadap hasil belajar ekonomi, Variabel kedisiplinan belajar secara parsial memberikan pengaruh yang positif dan signifikan terhadap hasil belajar ekonomi, Variabel motivasi dan kedisiplinan belajar secara simultan memberikan pengaruh yang positif dan signifikan terhadap hasil belajar ekonomi.

Hasil yang sama ditunjukkan pula oleh Husna, dkk (2013) yakni secara simultan terdapat pengaruh yang signifikan antara iklim kelas dan minat belajar terhadap hasil belajar siswa. Tingkat iklim kelas dalam kondisi tinggi dengan persentase $75 \%$ sedangkan tingkat minat belajar dalam kondisi cukup dengan persentase sebesar $25 \%$.

Dari hasil penelitian-penelitian diatas dapat disimpulkan bahwa secara bersama-sama (simultan) pengetahuan awal, kedisiplinan belajar dan iklim komunikasi kelas berpengaruh signifikan terhadap hasil belajar produktif Akuntansi siswa kelas XI Akuntansi SMK Negeri 3 Bangkalan. Hal ini sesuai dengan kenyataannya bahwa apabila pengetahuan awal siswa tinggi, kedisiplinan 
belajar siswa tinggi. Didukung dengan iklim komunikasi di kelas yang nyaman dan kondusif maka hasil belajar siswa tentunya akan meningkat.

Apabila siswa mempunyai banyak pengetahuan awal yang tentunya dijadikan landasan dasar untuk pembelajaran berikutnya dan pasti akan mempengaruhi siswa untuk disiplin dalam belajar baik itu di sekolah maupun dirumah serta didukung dengan iklim komunikasi kelas yang nyaman dan kondusif, sehingga akan timbul kekompakan dan komunikasi yang baik antara siswa dengan guru maupun antara sesama siswa, tentunya akan berpengaruh terhadap hasil belajar siswa yaitu dengan mendapatkan nilai yang tinggi selama pembelajaran produktif Akuntansi di SMK Negeri 3 Bangkalan.

Secara parsial, diperoleh hasil bahwa pengetahuan awal $\left(\mathrm{X}_{1}\right)$ secara parsial berpengaruh signifikan terhadap hasil belajar (Y). Sehingga semakin tinggi pengetahuan awal yang dimiliki siswa, maka semakin tinggi hasil belajar produktif Akuntansi siswa kelas XI jurusan Akuntansi SMK Negeri 3 Bangkalan. Nilai t-hitung pada variabel pengetahuan awal $\left(X_{1}\right)$ sebesar 6,644 dengan nilai signifikan 0,000 (kurang dari 5\% atau 0,05).

Berdasarkan hasil nilai $\mathrm{r}^{2}$ parsial sebesar 0,288 yang menunjukkan bahwa pengetahuan awal $\left(\mathrm{X}_{1}\right)$ secara parsial berpengaruh terhadap hasil belajar (Y) sebesar $28,8 \%$ sedangkan sisanya sebesar $71,2 \%$ dipengaruhi oleh variabel lain. Selain itu berdasarkan koefisien regresi pada variabel pengetahuan awal $\left(\mathrm{X}_{1}\right)$ adalah positif sebesar 0,922 . Hal ini menunjukkan apabila pendapat responden terhadap pengetahuan awal mengalami kenaikan sebesar 0,922, maka akan menaikkan hasil belajar siswa kelas XI Akuntansi SMKN 3 Bangkalan sebesar 0,922 , dengan asumsi variabel bebas lainnya konstan. Nilai positif pada variabel pengetahuan awal memiliki hubungan yang searah dengan hasil belajar siswa yaitu semakin tinggi pengetahuan awal siswa maka akan semakin tinggi hasil belajar siswa.

Hal ini didukung oleh teori Kujawa \& Huske (2003) pengetahuan awal (prior knowledge) merupakan kemampuan awal yang dimiliki seorang peserta didik bisa dijadikan sebagai titik tolak ukur untuk melihat seberapa besar perubahan perilaku yang terjadi setelah siswa mengikuti proses pembelajaran Akuntansi. Pengetahuan awal tidak hanya berkaitan dengan aspek pengetahuan saja, tetapi juga menyangkut sikap dan pengalaman yang telah dimiliki siswa selama belajar.

Ciri pokok dalam taraf pengetahuan adalah ingatan tentang sesuatu yang diketahuinya baik melalui pengalaman, belajar, ataupun informasi yang diterima dari guru pengajar, sehingga bisa lebih mengerti dan memahami ilmu Akuntansi dan dapat diterapkan dilingkungan kerja maupun masyarakat.

Hasil penelitian ini mendukung hasil penelitian terdahulu yang memiliki relevansi dengan variabel pengetahuan awal, yaitu penelitian Sjarkawi, dkk (2011) menujukkan pendekatan kontekstual berpengaruh terhadap hasil belajar, dan pengetahuan awal siswa berpengaruh terhadap hasil belajar, untuk lebih meningkatkan keabsahan penelitian ini maka perlu juga dilakukan penelitian dengan memakai model atau menggunakan metode ataupun strategi pembelajaran lain yang relevan sehingga dapat meningkatkan kemampuan hasil belajar siswa dan kemampuan siswa dalam berpikir secara kritis.

Dari hasil penelitian diatas, telah terbukti bahwa terdapat pengaruh yang signifikan antara pengetahuan awal siswa dengan hasil belajar siswa kelas XI 
Akuntansi SMK Negeri 3 Bangkalan. Dengan demikian dapat dikatakan apabila pengetahuan awal siswa stabil maka akan meningkatkan hasil belajar siswa. Hal ini sesuai dengan teori dan penelitian yang telah dilakukan sebelumnya yang menyebutkan bahwa semakin tinggi pengetahuan awal siswa, maka akan semakin tinggi pula hasil belajar siswa.

Selanjutnya, secara parsial diperoleh hasil bahwa kedisiplinan belajar $\left(\mathrm{X}_{2}\right)$ secara parsial berpengaruh signifikan terhadap hasil belajar (Y). sehungga semakin tinggi kedisiplinan belajar siswa, maka semakin tinggi hasil belajar produktif Akuntansi siswa kelas XI jurusan Akuntansi SMK Negeri 3 Bangkalan. Nilai t-hitung pada variabel kedisiplinan belajar $\left(\mathrm{X}_{2}\right)$ sebesar 7,156 dengan nilai signifikan 0,000 (kurang dari 5\% atau 0,05).

Berdasarkan hasil nilai $\mathrm{r}^{2}$ parsial sebesar 0,319 yang menunjukkan bahwa kedisiplinan belajar $\left(\mathrm{X}_{2}\right)$ secara parsial berpengaruh terhadap hasil belajar $(\mathrm{Y})$ sebesar $31,9 \%$ sedangkan sisanya sebesar $68,1 \%$ dipengaruhi oleh variabel lain. Selain itu berdasarkan koefisien regresi pada variabel kedisiplinan belajar $\left(\mathrm{X}_{2}\right)$ adalah positif sebesar 1,115. Hal ini menunjukkan apabila pendapat responden terhadap kedisiplinan belajar mengalami kenaikan sebesar 1,115, maka akan menaikkan hasil belajar siswa kelas XI Akuntansi SMKN 3 Bangkalan sebesar 1,115 , dengan asumsi variabel bebas lainnya konstan. Nilai positif pada variabel kedisiplinan belajar memiliki hubungan yang searah dengan hasil belajar siswa yaitu semakin tinggi kedisiplinan belajar siswa maka akan semakin tinggi hasil belajar siswa.

Hal ini didukung oleh teori Soegeng (2003) menyimpulkan bahwa disiplin belajar merupakan suatu kondisi yang tercipta dan terbentuk melalui proses dari serangkaian perilaku yang menunjukkan nilai-nilai ketaatan, kepatuhan, kesetiaan dan keteraturan atau ketertiban. Nilai-nilai tersebut telah menjadi bagian perilaku dalam kehidupannya dan perilaku tersebut tercipta melalui proses binaan melalui keluarga, pendidikan dan pengalaman.

Hasil penelitian ini mendukung hasil penelitian terdahulu yang memiliki relevansi dengan variabel kedisiplinan belajar, yaitu penelitian Sudarma \& Sakdiyah (2007) menujukkan bahwa adanya pengaruh yang positif dan signifikan motivasi berprestasi terhadap hasil belajar Akuntansi, dan adanya pengaruh yang positif dan signifikan disiplin belajar terhadap hasil belajar, serta adanya pengaruh yang positif dan signifikan partisipasi siswa dalam pembelajaran terhadap hasil belajar Akuntansi.

Selanjutnya penelitian Nokwanti (2013) menunjukkan hasil belajar siswa dipengaruhi oleh berbagai faktor seperti faktor disiplin belajar dan kemampuan berpikir siswa. Dengan disiplin belajar dan kemampuan berpikir yang baik, akan berdampak baik pula bagi perubahan perilaku dan hasil belajar siswa. Hasil penelitian menunjukkan bahwa adanya pengaruh positif tingkat disiplin belajar terhadap hasil belajar, dan adanya pengaruh positif kemampuan berpikir siswa terhadap hasil belajar.

Dari hasil penelitian diatas, telah terbukti bahwa terdapat pengaruh yang signifikan antara kedisiplinan belajar dengan hasil belajar siswa. Dengan demikian dapat dikatakan apabila kedisiplinan belajar stabil maka akan meningkatkan hasil belajar siswa. Hal ini sesuai dengan teori dan penelitian yang telah dilakukan sebelumnya yang menyebutkan bahwa semakin tinggi kedisiplinan belajar, maka akan semakin tinggi pula hasil belajar siswa. 
Terakhir, secara parsial diperoleh hasil bahwa iklim komunikasi kelas $\left(\mathrm{X}_{3}\right)$ secara parsial berpengaruh signifikan terhadap hasil belajar (Y). sehingga semakin tinggi iklim komunikasi kelas yang dimiliki siswa, maka semakin tinggi hasil belajar produktif Akuntansi siswa kelas XI jurusan Akuntansi SMK Negeri 3 Bangkalan. Nilai t-hitung pada variabel iklim komunikasi kelas $\left(\mathrm{X}_{3}\right)$ sebesar 7,288 dengan nilai signifikan 0,000 (kurang dari 5\% atau 0,05).

Berdasarkan hasil nilai $\mathrm{r}^{2}$ parsial sebesar 0,327 yang menunjukkan bahwa iklim komunikasi kelas $\left(\mathrm{X}_{3}\right)$ secara parsial berpengaruh terhadap hasil belajar $(\mathrm{Y})$ sebesar $32,7 \%$ sedangkan sisanya sebesar $67,3 \%$ dipengaruhi oleh variabel lain. Selain itu berdasarkan koefisien regresi pada variabel iklim komunikasi kelas $\left(\mathrm{X}_{3}\right)$ adalah positif sebesar 1,962. Hal ini menunjukkan apabila pendapat responden terhadap iklim komunikasi kelas mengalami kenaikan sebesar 1,962, maka akan menaikkan hasil belajar siswa kelas XI Akuntansi SMKN 3 Bangkalan sebesar 1,962 , dengan asumsi variabel bebas lainnya konstan. Nilai positif pada variabel iklim komunikasi kelas memiliki hubungan yang searah dengan hasil belajar siswa yaitu semakin tinggi iklim komunikasi kelas maka akan semakin tinggi hasil belajar siswa.

Hal ini didukung oleh teori Hoy \& Miskell (2000) iklim komunikasi kelas merupakan interaksi antar siswa dan guru pengajar yang mencakup nilai-nilai kepercayaan sosial, serta kualitas dari lingkungan di kelas dan sekolah yang terus menerus dialami oleh guru dan siswa yang dapat mempengaruhi tingkah laku mereka.

Hasil penelitian ini mendukung hasil penelitian terdahulu yang memiliki relevansi dengan variabel iklim komunikasi kelas, yaitu penelitian Tristeza (2013) menunjukkan terdapat hubungan yang signifikan antara iklim komunikasi kelas pada pembelajaran EFL, dan terdapat hubungan yang signifikan antara kompetensi komunikatif linguistik pada pembelajaran EFL. Temuan ini menunjukkan bahwa siswa merasakan bahwa iklim komunikasi kelas sebagai pendukung. Iklim komunikasi kelas yang mendukung ini berarti bahwa suasana komunikasi di dalam kelas memungkinkan fleksibilitas, eksperimentasi, dan kreativitas siswa, memahami dan mendengarkan siswa, menghormati perasaan siswa dan mengakui perbedaan siswa masing-masing, membuat siswa merasa aman, dan menghindari konflik dalam kelas adalah atribut guru untuk menguatkan iklim komunikasi yang mendukung di dalam kelas.

Dari hasil penelitian diatas, telah terbukti bahwa terdapat pengaruh yang signifikan antara iklim komunikasi kelas dengan hasil belajar siswa kelas XI Akuntansi SMK Negeri 3 Bangkalan. Variabel Iklim komunikasi kelas lebih dominan dan lebih banyak pengaruhnya kepada hasil belajar dibandingkan dengan variabel pengetahuan awal siswa dan variabel kedisiplinan belajar siswa. Hal ini sesuai dengan teori dan penelitian yang telah dilakukan sebelumnya yang menyebutkan bahwa semakin tinggi iklim komunikasi kelas, maka akan semakin tinggi pula hasil belajar siswa. Dari hasil penelitian iklim komunikasi kelas mempunyai pengaruh yang paling dominan terhadap hasil belajar siswa sehingga interaksi antar siswa dan guru pengajar yang mencakup nilai-nilai kepercayaan sosial, serta kualitas dari lingkungan di kelas dan sekolah dapat efektif serta terjalin dengan baik. Dengan menerapkan iklim kelas yang kondusif dan terjalinnya komunikasi yang aktif antara guru dengan siswa sehingga dapat 
menambah kekompakan dan proses belajar mengajar dapat berjalan dengan lancar.

\section{SIMPULAN}

Dari pembahasan yang telah diuraikan, maka dapat ditarik simpulan bahwa terdapat pengaruh yang signifikan pengetahuan awal, kedisiplinan belajar, dan iklim komunikasi kelas secara bersama-sama terhadap hasil belajar siswa di kelas XI Akuntansi SMKN 3 Bangkalan. Hal ini berarti semakin meningkat pengetahuan awal, kedisiplinan belajar dan iklim komunikasi kelas maka akan semakin meningkat pula hasil belajar siswa di kelas XI Akuntansi SMKN 3 Bangkalan. Pengetahuan awal berpengaruh signifikan terhadap hasil belajar siswa di kelas XI Akuntansi SMKN 3 Bangkalan. Hal ini berarti semakin meningkat pengetahuan awal siswa maka akan semakin meningkat pula hasil belajar siswa. Kedisiplinan belajar berpengaruh terhadap hasil belajar siswa di kelas XI Akuntansi SMKN 3 Bangkalan. Hal ini berarti semakin meningkat kedisiplinan belajar siswa maka akan semakin meningkat pula hasil belajar siswa. Iklim komunikasi kelas berpengaruh terhadap hasil belajar siswa di kelas XI Akuntansi SMKN 3 Bangkalan. Hal ini berarti semakin meningkat iklim komunikasi di kelas maka akan semakin meningkat pula hasil belajar siswa.

\section{DAFTAR RUJUKAN}

Fathurrochman, R., 2012. Pengaruh Membangun Pengetahuan Awal Atau Apersepsi Siswa Pada Kegiatan Pembelajaran. Jurnal pendidikan. Vol 3 No.4: 125-135.

Hoy, W. K, \& Miskell, 2000. Educational Administration: Theory, Research and Practic. New York: Random House.

Husna, R. Sri, B. Junaidi, M., 2013. Pengaruh Iklim Kelas Dan Minat Belajar Terhadap Hasil Belajar Siswa Pada Pelajaran Ekonomi Pada SMA. Jurnal Pendidikan Ekonomi. Vol. 65 No. 5: 7-16.

Silalahi, J., 2008. Pengaruh Iklim Kelas terhadap Motivasi Belajar. Jurnal Pembelajaran (Vol. 30 No.2). Padang: Universitas Negeri Padang Press.

Kujawa \& Huske, 2003. Critical Issue: Building on Prior Knowledge and Meaningful Student Contexts/Cultures, (Online), (http://www.ncrel.org), diakses 10 Agustus 2013.

Nokwanti, 2013. Pengaruh Tingkat Disiplin Dan Lingkungan Belajar Di Sekolah Terhadap Prestasi Belajar Siswa. Jurnal Ilmiah Pendidikan Ekonomi. (Online) Vol. 1 No. 1. (http://e-journal.ikip-veteran.ac.id) diakses 10 Agustus 2013.

Rusmiasih, 2013. Pengaruh Motivasi Dan Kedisiplinan Belajar Terhadap Hasil Belajar Ekonomi Siswa Kelas XI IPS Di SMAN 10 Purworejo. Jurnal Pendidikan Ekonomi. Vol 2. No.3: 10-18.

Santyasa, I.W, 2005. Model Pembelajaran Inovatif dan Implementasi Kurikulum Berbasis Kompetensi. Makalah disajikan dalam Penataran guru-guru SMP, SMA, dan SMK sekabupaten Jembrana, Juli 2005.

Sjarkawi, Sudiah \& Emosda, 2011. Pendekatan Kontekstual, Pengetahuan Awal Siswa dan Hasil Belajar IPA di SMP. Jurnal Teknologi, Vol 1 No. 2. 
Soegeng, P, 2003. Disiplin Kiat Menuju Sukses. Jakarta: Abadi

Sudarma, K. \& Sakdiyah, 2007. Pengaruh motivasi, Disiplin, dan Partisipasi siswa Dalam pembelajaran terhadap prestasi belajar Akuntansi. Jurnal Pendidikan Akuntansi, Vol 4. No. 2: 5-14.

Sudjana, 2005. Penilaian Hasil Proses Belajar Mengajar (Cetakan X). Bandung: Remaja Rosdakarya.

Sugiyono, 2011. Metode Penelitian Kuantitatif Kualitatif $R$ dan D. Bandung: Alfabeta.

Suwardjono, 2001. Akuntansi Pengantar: Konsep Proses Penyusunan Laporan pendekatan Sistem dan Terpadu. Yogyakarta: BPFE.

Tristeza, Danebeth, Narzoles, \& Glomo, 2008. Classroom Communication Climate and Communicative Linguistic Competence Of EFL Learner. Review Of Educational Research.

Depdiknas. 2010. Peraturan Menteri pendidikan nasional Republik indonesia Nomor 2 tahun 2010 Tentang Rencana strategis kementerian pendidikan nasional tahun 2010-2014. Jakarta: Depdiknas.

Winkel, W.S, 2004. Psikologi Pengajaran (Cetakan ke IV). Jakarta: Grasindo. 